\title{
MDGC-MS analysis of essential oils from Protium heptaphyllum (Aubl.) and their antifungal activity against Candida specie
}

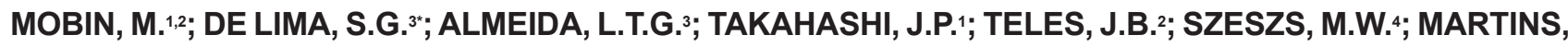
M.A. ${ }^{4}$; CARVALHO, A.A. ${ }^{3 ;}$ MELHEM, M.S.C. ${ }^{4}$

${ }_{1}$ Programa de Pós-Graduação, Coordenadoria de Controle de Doenças, Av. Dr. Arnaldo, 351, $1^{\circ}$ andar, São Paulo, SP. CEP 01246-900. 'Centro Universitário UNINOVAFAPI, Rua Vitorino Fernandes Orthiges, 6123, Uruguai, Teresina, PI. CEP 64073-505. 'Universidade Federal do Piauí, Departamento de Química. Av. Nossa Sra. de Fátima, Ininga, Teresina, PI. CEP 64049-550. ${ }^{4}$ Departamento de Micologia, Instituto Adolfo Lutz, Av. Dr. Arnaldo, 351, $8^{\circ}$ andar, São Paulo, SP. CEP 01246-002. *Autor para correspondência: sidney@ufpi.edu.br.

\begin{abstract}
Protium heptaphyllum is found in the Amazon region, and in various Brazilian states and South American countries. Also Known as almecega, it produces an oil resin used in traditional medicine as analgesic, anti-inflammatory, cicatrizant and expectorant, it is rich in pentacyclic triterpenes and essential oil. The main objective of this study was to analyze the chemical composition of $P$. heptaphyllumresin (OEPh) over different extraction times and to evaluate their antifungal activity against Candida species, obtained from gardeners with onychomycosis, using the disk diffusion method. The OEPh was obtained by hydrodistillation and analyzed by Multidimensional Gas Chromatography coupled with Mass Spectrometry (MDGC / MS). Candida species were obtained from lesions on the nails of horticulturist from a community garden in the city of Teresina, Piauí, Brazil. The antifungal activity in concentrations of 1000 $\mu \mathrm{g} / \mathrm{L}, 500 \mu \mathrm{g} / \mathrm{L}$ and $250 \mu \mathrm{g} / \mathrm{L}$, PROTOCOL M44-A2 (CLSI 2009) OEPh was tested. The main constituents identified were: I-limonene, $\alpha$-terpineol, p-cineol, o-cymene and $\alpha$-phellandrene, however, its composition varies significantly with extraction time. All species, except $C$. rugosa, were inhibited with halo ( $\geq 14 \mathrm{~mm}$ ) at $1000 \mu \mathrm{g} / \mathrm{L}$. C. krusei is naturally resistant to the drug fluconazole, but when tested with OEPh the clinical species (case 9) demonstrated sensitivity in three dilutions (halo $\leq 10 \geq 14$ ) and the standard strain was inhibited at concentration of 1000 $\mu \mathrm{g} / \mathrm{Lg} / \mathrm{L}$ (halo $14 \mathrm{~mm}$ ). A similar situation also occurred with the standard strain of C. parapsilosis (halo $\geq 11 \mathrm{~mm}$ ). OEPh has considerable antifungal activity, which merits further investigation for alternative clinical applications, since this species is widely distributed in our community, and it presents good yields, and also has important therapeutic applications.
\end{abstract}

Key words: Protiumheptaphyllum, Análise Química, Candida, susceptibilidade, onicomicoses

RESUMO: Análise MDGC-MS de óleos essenciais de Protium heptaphyllum (Aubl.) e sua atividade antifúngica contra espécies de Candida. Protium heptaphyllum é encontrada na região amazônica, em vários estados do Brasil e países da América do Sul. Conhecida como almecega produz uma resina oleosa usada na medicina popular como analgésica, antiinflamatória, cicatrizante e expectorante, é rica em triterpenos pentaciclicos e óleo essencial. O objetivo principal do presente trabalho foi analisar a composição química do óleo essencial da resina $\mathrm{P}$. heptaphyllum (OEPh) em diferentes tempo de extração e avaliarsuaatividade antifúngica contra espécies de Candida, isoladas de horticultores com onicomicoses, por método de disco-difusão. O OEPh foi obtido por hidrodestilação, analisado por Cromatografia Gasosa Multidimensinal Acoplada a Espectrometria de Massas (MDGC/MS). As espécies de Candida foram obtidas de lesões nas unhas de horticultores de uma horta comunitária na cidade de Teresina, Piauí, Brasil. Testou-se a atividade antifúngica do OEPhnas concentrações de $1000 \mu \mathrm{g} / \mathrm{L}, 500 \mu \mathrm{g} / \mathrm{L}$ e $250 \mu \mathrm{g} / \mathrm{L}$, protocolo M44-A2 (CLSI 2009). Os principais constituintes identificados foram $\mathrm{l}$ - limoneno, $\alpha$-terpineol, $p$-cineol, o-cimeno e $\alpha$-felandreno, entretanto, sua composição varia significativamente em decorrência do tempo de extração. Todas as espécies, exceto a C. rugosa, foram inibidas com halo $(\bar{X} \geq 14 \mathrm{~mm})$ na concentração de $1000 \mu \mathrm{g} / \mathrm{L}$. C. krusei é naturalmente resistente ao fármaco fluconazol, mas quando testado com OEPh,a

Recebido para publicação em 13/06/2015 
espécie clínico (caso 9) demonstrou sensibilidade nas três diluições (halo $\bar{X} \leq 10 \geq 14$ ) e a cepa padrão foi inibida na concentração de $1000 \mu \mathrm{g} / \mathrm{L}$ (halo $\bar{X}$ 14mm). Fato semelhante também ocorreu com a cepa padrão de C. parapsilosis (halo $\bar{X} \geq 11 \mathrm{~mm}$ ). O OEPh possui atividade antifúngica considerável, merecendo uma investigação mais aprofundada para aplicações clínicas alternativas, uma vez que esta espécie é amplamente distribuída em nossa comunidade, apresenta bom rendimento e, ainda, aplicações terapêuticas importantes.

Palavra-chaves: Protium heptaphyllum, Análise Química, Candida, Susceptibilidade, Onicomicoses

\section{INTRODUCTION}

Protium heptaphyllum (Aubl.) Marchand is a tree of the Burseraceae family, aromatic, evergreen or semi-deciduous, of humid sandy soil or dry and that reaches $10-20 \mathrm{~m}$ in height (Lorenzi \& Matos, 2008). These species are widely spread throughout tropical and subtropical regions, mainly in the Amazon Rainforest.

$P$. heptaphyllum is found in the Amazon region and in some Northeastern states, such as Bahia, Ceara, Piaui, as well as in other countries of South America (Colombia, Paraguay, Suriname and Venezuela) (Citó et al. 2003; Lorenzi \& Matos, 2008). It's recognized by the use of its leaves and bark as hemostatic, healing and anti-inflammatory, being used by the native people also as a nasal decongestant. Its stalk exudes an oily resin called almecega or breu-branco, which hardens on contact with air, of white-greenish color, pleasant aroma and rich in essential oils (Lorenzi \& Matos, 2008). Contraceptive, antineoplastic, healing, expectorant and antimicrobial action were also related others authors (Oliveira et al. 2005, Rüdiger et al. 2007).

Phytochemical studies performed on gums and oil resin, obtained from $P$. heptaphyllum revealed the presence of binary mixtures of triterpenes, especially $\alpha$ - and $\beta$-amyrins (Susunaga et al. 2001, Oliveira et al. 2005). The chemical constituents of essential oil of this resin analyzed by gas chromatography-mass spectroscopy (GC/MS) are mainly monoterpenes (Bandeira et al. 2001, Citó et al. 2003), but, phenylpropanoids were also identified in the product (Siani et al. 1999a). In the essential oil of P.heptaphyllum was detected p-cymene $(39.93 \%)$ and $\alpha$-tetradecane $(13: 38 \%)$ as the main constituents (Marques et al. 2010).

Due to the high cost of antifungal agents, the side effect reactions observed and the occurrence of resistance of some species to antifungal agents, the use of essential oils from plants has been target of studies given its potential as natural antifungal agents. Onychomycosis is a fungal infection of nail which affects about 6 to $8 \%$ of the adult population worldwide (Amartya et al. 2013). The yeasts, including Candida spp. account for 2-10\% of fungal nail infections (Thomas et al. 2010).

In view of the popular knowledge of the antimicrobial activity of almecega and the absence of studies on the antifungal activity of this material in clinical isolates, this study was conducted to analyze the chemical composition of the essential oil of Protium heptaphyllum and evaluate their antifungal activity against yeast species, obtained from lesions of workers with onychomycosis in a community garden located in the neighborhood "Dirceu", in the City of Teresina, Piaui, Brazil.

\section{MATERIAL AND METHOD}

\section{Plant Material}

The resin was collected at a private property in the municipality of Timon, Maranhão, Brazil, in December 2012 and kept under refrigeration until the time of extraction of the oil. The specie was identified in the Herbarium Graziela Barroso of the Federal University of Piaui, Brazil, and a voucher specimen was registered under No. 28730.

\section{Extraction}

The resin was subjected to hydrodistillation in a Clevenger type system. Six successive fractions were collected at intervals of one hour. In another system was collected a fraction after 6 continuous hours (6h cont), this fraction was used for the antifungal tests, due its higher yield. The extracted oils were dried with sodium sulfate $\left(\mathrm{Na}_{2} \mathrm{SO}_{4}\right)$, weighed and stored under refrigeration $\left(5^{\circ} \mathrm{C}\right)$.

\section{Analysis by gas chromatography-mass spectrometry}

The analysis was realized by Gas Chromatography System Multidimensional, MDGC/ GCMS-2010 SHIMADZU. In the chromatography of the components, an elite column Perkin Elmer mark with $30 \mathrm{~m}$ length and $0.25 \mathrm{~mm}$ in inner diameter and $0.25 \mu$ film thickness was used in the first dimension (FID).Nitrogen was used as carrier gas with a flow rate of $1.0 \mathrm{~mL} / \mathrm{min}$, injector temperature $260^{\circ} \mathrm{C}$, the column was programmed with an initial temperature

Rev. Bras. PI. Med., Campinas, v.18, n.2, p.531-538, 2016. 
of $50{ }^{\circ} \mathrm{C}(1 \mathrm{~min})$ followed by an increase of $5{ }^{\circ} \mathrm{C} / \mathrm{min}$ up to $180{ }^{\circ} \mathrm{C}(2 \mathrm{~min})$, then $10^{\circ} \mathrm{C} / \mathrm{min}$ to reach 225 ${ }^{\circ} \mathrm{C}$ (5 min).

In the second dimension similar column and analysis methods were used, GC-MS. The conditions of MS were: ion detector quadrupole operating in electron impact and impact energy of $70 \mathrm{eV}$; scan speed 1,000; and the fragments found in the range of 45 to $650 \mathrm{Da}$.

The identification of the essential oil components was performed by comparing the retention indices, interpretation of the fragmentation pattern of the respective mass spectra, comparison with the database of the analysis system (being considered only the spectra with index of equal similarity or greater, at $95 \%$ ) and with literature data. The pattern solution of $n$-alkanes $\left(\mathrm{C}_{8}-\mathrm{C}_{20}\right)$ was used for the calculation of the index of Kolvats, and this value was compared to the one described in the literature (Adams 2007, Costa et al. 2010).

\section{Antifungal activity}

To evaluate the antifungal activity of the essential oil of $P$. heptaphyllum resin, we used disk diffusion tests that were performed in the Research Laboratory of the University Center UNINOVAFAPI, according to the protocol M44-A2 (CLSI 2009).

A suspension was prepared for each species of yeast with fresh culture of $24 \mathrm{~h}$ of clinical isolates of: Candida krusei, C. albicans, C. parapsilosis, C. metapsilosis, C. rugosa, C. guillermondii. The identified agents came from lesions of onychomycosis of workers in a community garden located at Dirceu district, city of Teresina, State of Piaui, Brazil (after being approved by the research ethics committee 0207.0.043.000-10). 25 $\mu \mathrm{L}$ of each yeast suspension was inoculated on Petri dishes containing culture medium Mueller-Hinton (Difco ${ }^{\mathrm{T}}, \mathrm{USA}$ ), with glucose at $2 \%$ and methylene blue (MGB agar). Three oil concentrations were used, being $1000 \mu \mathrm{g} / \mathrm{L}, 500 \mu \mathrm{g} / \mathrm{L}$ and $250 \mu \mathrm{g} / \mathrm{L}$.
Withdrew $20 \mu \mathrm{L}$ of each concentration, placed in sterile and standardized discs with a diameter of 6 $\mathrm{mm}$, which were then deposited on the surface of the MGB medium. For quality control with strains of C.parapsilosis ATCC 22019 and C. krusei ATCC 6258 , and as negative control, we used solvent acetone/water at $15 \%$. All tests were carriedout in triplicate.

The descriptive analysis of the categorical variables was carried out by reading the absolute and relative frequencies (\%), while in the numeric variables, the average position and standard deviation variability (SD) measurements were taken.

\section{RESULTS AND DISCUSSION}

\section{Performance and Analysis of Chemical Constituents}

The MDGC/GCMS-2010 is a MDGC system that offers excellent performance and highly reproducible separation with "multi-deans switching" technology, supporting the analysis of complex matrices, such as rocks extract samples, oils (petroleum), aromas and optical isomers. In this research work, we did not identified significant changes in the oil composition when using similar polarity column, however we focused especially on the separation and quantification power in the first dimension (MDGC) and identification in the second dimension (GCMS). The analysis of the essential oil of $P$. heptaphyllum resin by MDGC-MS allowed the identification of 26 constituents, predominantly monoterpenes (Table 1). The constituents present in greater abundance were: I-limonene, a-terpineol, $p$-cineole and o-cymene (Figure 1 ) in the first hour of extraction, with yield of $0.62 \%$.

It was possible to observed that as the extraction time is increased, the percentage of l-limonene (constituent in greater abundance in the first hour of extraction) decreases as the

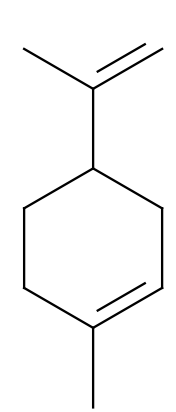

I-Limonene

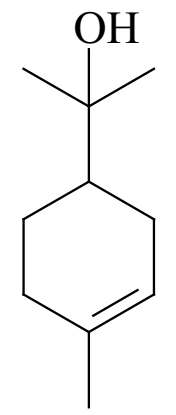

$\alpha$-Terpineol<smiles>CC(C)C12CCC(C)(CC1)O2</smiles>

p-Cineole

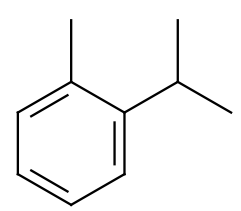

o-Cymene

FIGURE 1. Chemical structure of the main components of the essential oil of $P$. heptaphyllum. 
concentration of a-terpineol increases, as well as other compounds that did not appear in the first hours begin to emerge. This fact is explained by the secondary reactions that may occur in the system due to the constant heating.

Research on antifungal effects of $D L$ limonene against various yeast species was presented by Ünal et al. (2012). More specifically, these authors demonstrated that DL-limonene at a concentration of $0.20 \%(w \mathrm{~V}-1)$ inhibited cell growth, ethanol formation, and sugar utilization by S. cerevisiae.
The a-terpineol is a major component of the essential oil of many plants and has been reported to enhance the permeability of skin to lipid- soluble compounds (Williams \& Barry, 1991). Antimicrobial effect of linalool and a-terpineol against periodontopathic and cariogenic bacteria was evaluated by Park et al. (2012). The $\alpha$-terpineol has also been described to have anti-inflammatory properties (Held et al. 2007), antibacterial (Kotan et al. 2007) and antifungal activities (Pitarokili et al. 2002). Hassan et al. (2010)showed that a-terpineol also has a potential anticancer agent. The p-cineole is responsible for several activities, amongst which,

TABLE 1. Extraction time influence on the chemical composition (\%) of the essential oil of $P$. heptaphyllum resin.

\begin{tabular}{|c|c|c|c|c|c|c|c|c|}
\hline \multirow[b]{2}{*}{ Constituents } & \multirow[b]{2}{*}{ IK ${ }^{*}$} & \multicolumn{7}{|c|}{ Extration Time } \\
\hline & & $1 \mathrm{~h}$ & $2 \mathrm{~h}$ & $3 \mathrm{~h}$ & $4 h$ & $5 \mathrm{~h}$ & $6 \mathrm{~h}$ & $6 \mathrm{~h}$ cont \\
\hline a-Tujeno & 924 & & & & & & & 0.40 \\
\hline a-Pinene & 932 & 1.05 & - & 1.17 & 0.94 & 0.71 & 0.51 & 1.17 \\
\hline Sabenene & 969 & - & - & - & 0.18 & - & - & \\
\hline$\beta$-Pinene & 974 & - & - & - & 0.38 & - & - & 0.32 \\
\hline a-Phelandrene & 1002 & 11.38 & 8.11 & 7.77 & 7.77 & 7.42 & 6.90 & 2.41 \\
\hline б 3-Carene & 1008 & 9.67 & 6.15 & 7.10 & 7.04 & 6.22 & 5.92 & 6.14 \\
\hline o-Cymene & 1022 & 12.52 & 10.82 & 9.38 & 9.24 & 8.12 & 8.06 & 17.43 \\
\hline I-Limonene & 1024 & 26.31 & 21.31 & 16.49 & 17.19 & 15.46 & 15.85 & 36.01 \\
\hline$\beta$-Phelandrene & 1025 & $\mathrm{c} / \mathrm{a}$ & Ic/a & Ic/a & Ic/a & Ic/a & Ic/a & 1.49 \\
\hline$p$-Cineole & 1026 & 18.98 & 14.34 & 8.73 & 9.96 & 8.59 & 8.06 & 18.68 \\
\hline y-Terpinene & 1054 & - & - & - & - & 0.35 & - & \\
\hline Cumicaldehyde & 1077 & - & - & - & - & 0.30 & - & \\
\hline$\alpha$-Terpinolene & 1086 & 0.86 & - & 1.73 & 1.50 & 1.60 & 1.43 & \\
\hline$\beta$-Linalool & 1095 & - & - & 1.05 & 0.83 & - & 0.70 & \\
\hline Cuminol & 1104 & - & - & - & 0.47 & 0.3 & - & \\
\hline Mircene & 1119 & & & & & & & 0.76 \\
\hline I-Camphor & 1141 & - & - & - & 0.72 & 0.70 & - & \\
\hline 4-Terpineol & 1174 & - & - & 2.14 & 1.65 & 1.91 & 1.74 & 0.63 \\
\hline Cripton & 1183 & & & & & & & 0.35 \\
\hline a-Terpineol & 1186 & 19.22 & 32.60 & 30.05 & 31.14 & 30.91 & 32.57 & 6.60 \\
\hline Cis-Pinocarveol & 1187 & - & - & 2.97 & 3.67 & 4.16 & 4.63 & \\
\hline Verbenone & 1204 & - & - & - & 0.45 & - & - & \\
\hline Cis-Carveol & 1226 & - & - & - & - & 0.52 & 0.53 & 0.31 \\
\hline Carvone & 1239 & - & - & 0.86 & - & 0.77 & 0.76 & 1.06 \\
\hline Carvotanacetone & 1244 & - & - & - & - & 1.69 & 1.33 & \\
\hline Piperitone & 1249 & - & - & 2.51 & 2.16 & - & - & 0.85 \\
\hline Carvacrol & 1298 & - & - & 1.21 & 1.55 & 2.25 & 2.87 & \\
\hline Methyleugenol & 1403 & - & - & - & 0.66 & 1.13 & 1.22 & \\
\hline$\beta$-Sesquiphelandrene & 1521 & - & - & - & - & 0.36 & - & \\
\hline Elemol & 1537 & - & - & - & - & 0.50 & - & \\
\hline Yield (\%) & & 0.62 & 0.25 & 0.17 & 0.17 & 0.11 & 0.06 & 1.38 \\
\hline Non- Identified & & - & 6.66 & 6.31 & 2.51 & 6.01 & 6.93 & 4.89 \\
\hline
\end{tabular}

*Indice de Kolvats (Adams, 2007). Ic/a = low concentration or absent. 
it is used in the treatment of skin infections (Hammer et al. 2002). Recently, Santin et al. (2014) showed that the major compounds identified in the essential oil Origanum vulgare, are; thymol, 4-terpineol, a-terpinene which are responsible for antifungal activity against the yeast $M$. pachydermatis.

In the world market, much of the a-terpineol comes from synthetic route that uses pinene and turpentine as precursor substances (Baptistella et al. 2009) and other synthetic routes from I-limonene and nerol have been studied. The a-terpinil trifluoroacetate when derivative from $d$-limonene, through the addiction of Markvnikov using trifluoroacetic acid can be converted into d- $\alpha-$ terpineol by hydrolysis (Yuasa \&Yuasa, 2006), as illustrated in (Figure 2).

The chemical composition of the oil from the resin of Protium varies according to time of year and the region where the material was collected. Previous studies performed with the same resin, but acquired from other sources showed that the chemical composition of the oil undergoes significant changes. Citó et al. (2003) found as major compounds $\beta$-terpinilacetate $(23.2 \%)$, limonene $(18.2 \%)$ and $\beta$-ocimene $(11.2 \%)$, in resin from Teresina (Piaui , Brazil), while the oil obtained by Marques et al. (2010) in Cruzeiro do Sul, State of Acre (Brazil) showed p-cymene $(39.93 \%)$, n-tetradecane $(13.38 \%)$ and dihydro-4-carene $(11.69 \%)$. The (Table 2 ) shows the major components identified in the essential oil of $P$. heptaphyllum collected in different regions.

The differences in the composition of essential oils extracts of $P$. heptaphyllum may occur due to other factors including in traspecific genetic differences in plants, seasonal and environmental influences such as temperature, humidity, soil, and time of collection. The time and method of storage of the resin is an important aspect to be considered, especially in view of the essential oils consisting mainly of monoterpenes and light compounds (volatiles, heat-unstable and photolabile) (Mattana et al. 2015; Rüdiger et al. 2007).

\section{Antifungal Activity}

So far there are no reports in the literature on the use of OEPh for the treatment of onychomycosis, which is considered a crucial disease in public health due to its high incidence and worldwide prevalence, representing more than $50 \%$ of all onychopathies (Bokhari et al. 1999, Thomas et al. 2010, Zotti et al. 2011). Performance evaluation of disk diffusion method for determining the antifungal activity of OEPh, against yeasts agents of onychomycosis are shown in (Table3).

It was observed that all the species, except C. rugosa, were inhibited with halo $\geq 14 \mathrm{~mm}$ at 1000 $\mu \mathrm{g} / \mathrm{L}$. The C. krusei(case 9), C. guilliermondii(case 54) and C. albicans (cases 71,89$)$ were inhibited in all three concentrations (halo $12 \leq \bar{X} \geq 14 \mathrm{~mm}$ ). Fluconazole is an antifungal that has good clinical activity against most Candida spp. However, C. krusei is naturally resistant to this drug, but when tested with OEPh the clinical species showed sensitivity in three dilutions, and standard strain was inhibited at $1000 \mu \mathrm{g} / \mathrm{L}$ (halo $\geq 14 \mathrm{~mm}$ ). A similar situation also occurred with the standard strain of C. parapsilosis, which at the same concentration showed halo $\bar{X} \geq$ $11 \mathrm{~mm}$. Comparing the performance of OEPh and fluconazole in relation to other Candida species, the drug Fluconazole is more reactive than the tested oil (halo $20 \leq \geq 35 \mathrm{~mm}$ ).

Values of inhibition halo equal to or greater than $8 \mathrm{~mm}$ or $10 \mathrm{~mm}$ are indicative of the presence of inhibitory activity (Fenner et al. 2006, Lima et al. 2006, Aibinu et al. 2007, Dutta et al. 2007, Nascimento et al. 2007, Packer \& Luz, 2007, Scorzoni et al. 2007, Pozzati et al. 2008, Menezes et al. 2009, Almeida et al. 2011, Cavalcanti et al. 2012). These values do not predict clinical response, but are associated to products with pharmacological potential in studies of drug screening (Cavalcanti et al. 2012).

Although the disk diffusion test is one of the most used and accepted for the search for new drugs, the results obtained in tests with this method are difficult to interpret. The substances used to
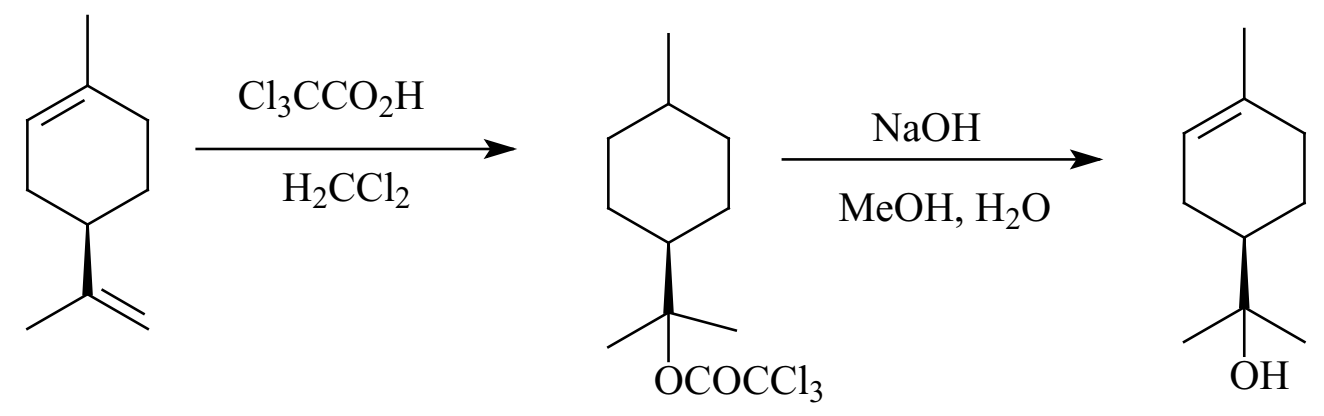

(1)

FIGURE 2. Synthesis of a-terpineol (3) from $d$-limonene (1) and $\alpha$ - terpinyltrichloroacetate (2) 
TABLE 2. Literature review of major constituents of essential oil of $P$. heptaphyllum.

\begin{tabular}{|c|c|c|c|}
\hline Constituents & Region & Material & Reference \\
\hline $\begin{array}{l}\text { p-Cimene }(11.00 \%) \text {, limonene }(4.20 \%) \text {, terpinolene } \\
(21.8 \%) \text {, dilapiol }(16.1 \%) .\end{array}$ & $\begin{array}{l}\text { Reserve of Campina, City of Manaus, } \\
\text { State of of Amazonas Brazil }\end{array}$ & Resin & Siani et al., 1999a \\
\hline $\begin{array}{l}\text { terpinolene }(28.5 \%) \text {, limonene }(16.9 \%) \text {, a-felandrene } \\
(16.7 \%) \text { e } \alpha \text {-pinene }(10.5 \%) \text {. }\end{array}$ & Crato (State of Ceará) Brazil & Resin & $\begin{array}{l}\text { Bandeira et al. } \\
2001\end{array}$ \\
\hline myrcene (18.6\%) e $\beta$-caryophyllene (18.6\%) & Crato, Brazil & Leaves & $\begin{array}{l}\text { Bandeira et al. } \\
2001\end{array}$ \\
\hline a-pinene (71.2 \%). & Crato, Brazil & Fruits & $\begin{array}{l}\text { Bandeira et al. } \\
2001\end{array}$ \\
\hline $\begin{array}{l}\alpha \text {-terpinene }(18.0 \%), p \text {-cimene }(36.0 \%), y \text {-terpinene } \\
(12,0 \%) .\end{array}$ & $\begin{array}{l}\text { Reserve of Campina, Manaus - } \\
\text { Amazonas, Brazil }\end{array}$ & FreshResin & Siani et al, 1999b \\
\hline $\begin{array}{l}p \text {-Cimene }(11.0 \%) \text {, terpinolene, } p \text {-cimen-8-ol }(11.0 \%) \text {, } \\
\text { dilapiol }(16.0 \%)\end{array}$ & $\begin{array}{l}\text { Reserve of Campina, Manaus - } \\
\text { Amazonas, Brazil }\end{array}$ & AgedResin & Siani et al, 1999b \\
\hline $\begin{array}{l}\text { terpinilacetate }(23.2 \%) \text {, limonene }(18.2 \%) \text { e } \\
\beta \text {-ocimene }(11.2 \%)\end{array}$ & $\begin{array}{l}\text { Obtained in the market in Teresina, State } \\
\text { of Piaui, Brazil }\end{array}$ & Resin & Citó et al, 2003 \\
\hline $\begin{array}{l}\text { 9-epi (E)-cariophilene }(21.4 \%) \text {, trans-isolongifolanone } \\
(10.3 \%) \text { e } 14 \text {-hidroxi-9-epi- } \beta \text {-caryophyllene }(16.7 \%)\end{array}$ & $\begin{array}{l}\text { Biological Reserve of Guadalupe - } \\
\text { State of Pernambuco, Brazil }\end{array}$ & Leaves & Pontes et al, 2007 \\
\hline a-terpinene $(46.7 \%)$ & Biological Reserve of Guadalupe, Brazil. & Fruits & Pontes et al, 2007 \\
\hline $\begin{array}{l}\text { Terpinolene }(15.45 \%) \text {, } \beta \text {-elemene }(22.09 \%) \text {, } \\
\beta \text {-carifilene }(11.11 \%) \text {. }\end{array}$ & $\begin{array}{l}390 \mathrm{~km} \text { from Manaus, State of } \\
\text { Amazonas (Brazil) road to Manaus- } \\
\text { Caracarai (BR 174) }\end{array}$ & Leaves & Zoghbi et al, 1995 \\
\hline Terpinolene $(40.28 \%)$ & $\begin{array}{l}390 \mathrm{~km} \text { from Manaus, State of } \\
\text { Amazonas (Brazil) road to Manaus- } \\
\text { Caracarai (BR } 174\end{array}$ & Stalk & Zoghbi et al, 1995 \\
\hline $\begin{array}{l}p \text {-cimene }(39.93 \%), n \text {-tetradecane }(13.38 \%) \text { e dihidro- } \\
\text { 4-carene }(11.69 \%)\end{array}$ & Cruzeiro do Sul, Stateof Acre, Brazil. & Resin & $\begin{array}{l}\text { Marques et al, } \\
2010\end{array}$ \\
\hline
\end{tabular}

TABLE 3. Performance evaluation (halo inhibition, $\mathrm{mm}$ ) of the disk diffusion method for determination of antifungal activity of the essential oil of $P$. heptaphyllum against yeast species

\begin{tabular}{|c|c|c|c|c|c|c|c|c|c|}
\hline \multirow{4}{*}{ Cases } & \multirow{4}{*}{ Species } & \multicolumn{8}{|c|}{ Oil Concentration } \\
\hline & & \multirow{2}{*}{\multicolumn{2}{|c|}{$1000 \mu \mathrm{g} / \mathrm{L}$}} & \multirow{2}{*}{\multicolumn{2}{|c|}{$500 \mu \mathrm{g} / \mathrm{L}$}} & \multirow{2}{*}{\multicolumn{2}{|c|}{$250 \mu \mathrm{g} / \mathrm{L}$}} & \multirow{2}{*}{\multicolumn{2}{|c|}{$\begin{array}{c}\text { Fluconazol disc } \\
25 \mu \mathrm{g}\end{array}$}} \\
\hline & & & & & & & & & \\
\hline & & $\bar{X}$ & $\mathrm{DP}$ & $\bar{X}$ & $\mathrm{DP}$ & $\bar{X}$ & DP & $\bar{X}$ & $\mathrm{DP}$ \\
\hline 09 & Candida krusei & 14 & - & 10 & 10 & 10 & - & - & - \\
\hline 11 & C. parapsilosis & 11.3 & 1.2 & - & - & - & - & 34 & - \\
\hline 18 & C. africana & 13.3 & 1.2 & 9.3 & 9.3 & 9.3 & 1.2 & 30 & - \\
\hline 30 & C. parapsilosis & 11.3 & 2.3 & - & - & - & - & 35 & 9.22 \\
\hline 34 & C. albicans & 13.3 & 1.2 & 9.3 & 9.3 & 9.3 & 1.2 & 32 & - \\
\hline 43 & C. metapsilosis & 12.7 & 1.2 & - & - & - & - & 26 & - \\
\hline 44 & C. albicans & 11.3 & 2.3 & - & - & - & - & 20 & - \\
\hline 54 & C. guilliermondii & 14 & 2.0 & 10 & 10 & 10 & - & - & - \\
\hline 58 & C. guilliermondii & 10 & - & - & - & - & - & 20 & - \\
\hline 63 & C. parapsilosis & 11.3 & 1.2 & 9.3 & 9.3 & 9.3 & 1.2 & 32 & - \\
\hline 71 & C. albicans & 14.7 & 2.3 & 10 & 10 & 10 & - & 32 & - \\
\hline 89 & C. albicans & 14 & - & 12 & - & 10 & - & 28 & - \\
\hline 90 & C. rugosa & - & - & - & - & - & - & 20 & - \\
\hline \multirow[t]{3}{*}{104} & C. metapsilosis & 12.7 & 2.3 & - & - & - & - & 20 & - \\
\hline & C. parapsilosis ATCC 22019 & 11.3 & 2.3 & 8.0 & 8.0 & 8.0 & - & 30 & - \\
\hline & C. krusei ATCC 6258 & 14 & 2.0 & - & - & - & - & - & - \\
\hline
\end{tabular}

$\overline{\bar{X}}$, average; (-) null average due to the absence halo; standard deviation (SD) calculated for tests performed in triplicate. 
dilute the compounds may constitute relevant factors affecting the result of inhibition of the isolates evaluated. For example, the dimethyl sulfoxide (DMSO), acetone and ethyl and methyl alcohols are organic solvents often cited in the specialized literature on plant products; however, the correct evaluation of the influence of the diluent on the result of inhibition obtained is required.

In this study we investigated solvents such as ethanol, methanol and acetone (data not shown) verifying that only the last of these diluents showed no inhibitory activity itself against clinical isolates and standard strains. Thus, the study was conducted by employing acetone in water (15\%) as diluent. Moreover, the characteristics of the products evaluated, such as volatility, viscosity, hydrophobicity are factors of impact on the results. Thus, the different products have physico-chemical properties that interfere with diffusion in the agar.

Lima et al. (1993) evaluated the antifungal activity of the essential oil of various species of plants, against 16 species of dermatophytes (Epidermophyton, Microsporum, Trichophyton), and $80 \%$ of these plants showed antifungal activity, except the $P$.heptaphyllum, which presented $\beta$-terpinolene, $L$-phelkandrene e $\alpha$-pinene as majority constituents. It is important to note that in this study, these constituents are in low relative abundance ( $L$-phelkandrene $-1.49 \%$, a-pinene-1.17\%) or absent ( $\beta$-terpinolene), demonstrating the importance of the collected region in composition and also that these compounds can not be responsible for such activity.

The essential oil obtained from the resin of Protium heptaphyllum when analyzed by MDGCMS and showed as major constituents I-limonene, $\alpha$-terpineol and $p$-cineol. The analysis of the fractions collected at intervals of 1 hour showed that the abundance of the main components decrease, while the a-terpineol increases over time due to secondary reactions when subjected to heating. As compared to literature data, our study evidenced some differences in the chromatographic profile as well as in quantitative composition of essential oil P. heptaphyllum.

This study presented considerable antifungal activity of Protium oil resin, inhibiting species of Candida, by disk diffusion method, with diameter of halos ( $\bar{X} \geq 14 \mathrm{~mm}$ ), which cause a broad spectrum of invasive superficial infections and nail infections that are public health problems.

Though the literature data reports the antifungal activity of some constituents identified in this study, there is still a need for more detailed studies of OEPh, including activity in vivo for possible alternative clinical applications, since this specie is widely distributed in our community, it presents good yield and also important therapeutic applications.

\section{ACKNOWLEDGMENTS}

We acknowledge the support of UNINOVAFAPI University Center, the Laboratory of Geochemistry Analysis (LAGO) of the Federal University of Piaui and Mycology Laboratory of the Adolfo Lutz Institute - SP, and to Boris Timah for grammatical corrections.

\section{REFERENCE}

ADAMS, R.P. Identification of essential oils components by gas chromatography/mass spectroscopy. 4. ed. Carol Stream, USA: Copyrighted Material, 2007. 804p.

AIBINU, I. et al. Evaluation of the antimicrobial properties of different parts of Citrus aurantifolia (lime fruit) as used locally. African Journal of Traditional, Complementary and Alternative medicines, v.4, n.2, p185-190, 2007.

ALMEIDA, L.D.F.D.D. et al. Screening of antifungal activity of essential oils on Candida albicans. Revista Brasileira de Ciências da Saúde v.14, n.4, p.51-56, 2011.

AMARTYA DE, N. N.; TAHER, Abu. Onychomycosis and Its Treatment. International Journal of advances in Pharmacy, Biology and Chemistry, v. 2, n.1, p.123129,2013

BANDEIRA, N.P. et al. Essential oil composition of leaves, fruits and resin of Protium heptaphyllum (Aubl.) March. Journal of Essential Oil Research v.13, n.1, p.33-34, 2001.

BAPTISTELLA, L.H.B. et al. Preparação do (+)-a-terpineol a partir do (+)-limoneno: monoterpenos de odor agradável em um projeto para química orgânica experimental. Química Nova, v.32, n.4, p.1069-1071, 2009.

BOKHARI, M.A. et al. Onychomycosis in Lahore, Pakistan. International Journal of Dermatology, v.38, p.591-595, 1999.

CAVALCANTI, Y.W. et al. Antifungal activity of brazilian plant extracts against Candida strains. Revista Brasileira de Ciências da Saúde v.16, n.1, p.43-48, 2012.

CITÓ, A.M.G.L. et al. Resina de Protium heptaphyllum march (Burseraceae): composição química do óleo essencial e avaliação citotóxica frente a Artemia salina Leach. Anais da Associação Brasileira de Química, v.52, n.2, p.71-73, 2003

CLSI -Clinical and Laboratory Standards Institute-CLSI. Method for antifungal disk diffusion susceptibility testing of yeasts. 2ed. CLSI document M44-A2. Pennsykvania, USA, v.29, n.17, p.1-23, 2009.

COSTA, J.G.M.D. et al. Composição química e toxicidade de óleos essenciais de espécies de Piper frente a larvas de Aedes aegypti L. (Diptera: Culicidae). Latin American Journal of Pharmacy, v.29, n. 3, p.463467, 2010.

DUTTA, B.K. et al. Anticandidial activity of some essential oils of a mega biodiversity hotspot in India. Mycoses, v.50, n.2, p.121-124, 2007.

FENNER, R. et al. Plantas utilizadas na medicina popular brasileira com potencial atividade antifúngica. Revista Brasileira de Ciências Farmacêuticas, v.42, n.3, p.369-393, 2006. 
HASSAN, S. B. et al. Alpha terpineol: a potential anticancer agent which acts through suppressing NF-KB signalling. Anticancer Research, v.30, p.1911-20, 2010.

HAMMER, K.A. et al. In vitro activity of Malaleuca alternifolia (tea tree) oil against dermatophytes and other filamentous fungi. Journal of Antimicrobial Chemotherapy, v.50, n.2, p.195-199, 2002.

HELD, S. et al. Characterization $\alpha$-terpineol as an antiinflammatory component of orange juice by in vitro studies using oral buccal cells. Journal of agricultural and food chemistry, v.55, n.20, p.8040-8046, 2007.

KOTAN, R. et al. Screening of antibacterial activities of twenty-one oxygenated monoterpenes Zeitschrift für Naturforschung C, v.62, n.7-8, p. 507-513, 2007.

LIMA, E.O.; GOMPERTZ, O.; GIESBRECHT, A.; PAULO, M.Q. In vitro antifungal activity of essential oils obtained from officinal plants against dermatophytes. Mycoses, v.36, n.9-10, 1993, p.333-336.

LIMA, I.O. et al. Atividade antifúngica de óleos essenciais sobre espécies de Candida. Brazilian Journal of Pharmacognosy, v.16, n.2, p.197-201, 2006.

LORENZI, H.; MATOS, F.J.A. Plantas medicinais no Brasil: nativas e exóticas. 2.ed. Nova Odessa, SP: Plantarum, 2008. 544p.

MARQUES, D.D. et al. Chemical composition of the essential oils from two subespécies of Protium heptaphyllum. Acta Amazonica, v.40, n.1, p.227-230, 2010.

MATTANA, R.S. et al. Efeitos de diferentes tempos de extração no teor e composição química do óleo essencial de folhas de pariparoba [Pothomorpheumbellata (L.) Miq.]. Revista Brasileira de Plantas Medicinais, v.17, n.1, p.150-156, 2015.

MENEZES, T.O.A. et al. Avaliação in vitro da atividade antifúngica de óleos essenciais e extratos de plantas da região amazônica sobre cepa de Candida albicans. Revista de Odontologia da UNESP, v.38, n.3, p.18491, 2009.

NASCIMENTO, P.F.C. et al. Atividade antimicrobiana dos óleos essenciais: uma abordagem multifatorial dos métodos. Revista Brasileira de Farmacognosia, v.17, n.1, p.108-113, 2007.

OLIVEIRA, F.A. et al. Protective effect of $\alpha$ - and $\beta$-amyrin, a triterpene mixture from Protium heptaphyllum (Aubl.) March. trunk wood resin, against acetaminophen-induced liver injury in mice. Journal Ethnopharmacology, v.98, p.10-18, 2005.

PACKER, J.F.; LUZ, M.M.S. Método para avaliação e pesquisa da atividade antimicrobiana de produtos de origem natural. Revista Brasileira de Farmacognosia, v.17, n.1, p.102-107, 2007.

PARK, Soon-Nang et al. Antimicrobial effect of linalool and $\alpha$-terpineol against periodontopathic and cariogenic bacteria. Anaerobe, v.18, n.3, p.369-372, 2012.

PITAROKILI, D. et al. Composition and antifungal activity on soil-borne pathogens of the essential oil of Salvia sclarea from Greece. Journal of agricultural and food chemistry, v.50, n.23, p. 6688-6691, 2002.

PONTES, W.J.T. et al. Chemical composition and acaricidal activity of the leaf and fruit essential oils of Protium heptaphyllum (Aubl.) Marchand (Burseraceae). Acta Amazonica, v.37, n.1, p.103-109, 2007.

POZZATI, P. et al. In vitro activity of essential oils extracted from plants used as spices against fluconazole-resistant and fluconazole-susceptible Candida spp. Canadian journal of microbiology, v.54, n.11, p.950-956, 2008.

RÜDIGER, A.L. The chemistry and pharmacology of the South America genus Protium Burm. f. (Burseraceae). Pharmacognosy reviews, v.1, n.1, p.93-104, 2007.

SANTIN, R. et al. Atividade antifúngica do óleo essencial de Origanum vulgare frente a Malassezia pachydermatis. Arquivo brasileiro de medicina veterinaria e zootecnia $=$ Brazilian journal of veterinary and animal sciences, v.66, n.2, p.367-373, 2014.

SCORZONI, L. et al. Comparative study of disk difusion and microdilution methods for evaluation of antifungal activity of natural compounds against medical yeasts Candida spp and Cryptococcus sp. Revista de Ciências Farmacêuticas Básica e Aplicada, v.28, n.1, p.25-34, 2007.

SIANI, A.C. et al. Volatile constituents from oleo resin of Protium heptaphyllum (Aubl.) March. Journal of Essential Oil Research, v.11, n.1, p.72-74, 1999.

SIANI, A.C. et al. Evaluation of anti-inflammatory-related activity of essential oils from leaves and resin of species of Protium. Journal of Ethnopharmacology, v.66, p.57-69, 1999.

SUSUNAGA, G. S. et al. Triterpenes from the resin of Protium heptaphyllum.Fitoterapia, v. 72, n. 6, p.709711, 2001.

THOMAS J. et al. Toenail onychomycosis: an important global disease burden Journal of Clinical Pharmacy and Therapeutics, v.35, n.5, p.497- 519, 2010.

ÜNAL, M.Ü. et al. Research on antifungal and inhibitory effects of DL-limonene on some yeasts. Turkish Journal of Agriculture and Forestry, v.36, n.5, p.576582, 2012.

WILLIAMS. A.C.; BARRY, B.W. Terpenes and the lipid-protein-partitioning theory of skin penetration enhancement. Pharmaceutical research, v.8, n.1, p.17-24, 1991.

YUASA, Y.; YUASA, Y. A pratical synthesis of $d-$ a-terpineol via Markovnikov addition of d-limonene using trifluoroacetic acid. Organic process research \& development, v.10, n.6, p.1231-1232, 2006.

ZOGHBI, M.G.B.; MAIA, J.G.S.; LUZ, A.I.R. Volatile Constituents from leaves and stems of Protium heptaphyllum (Aubl.) March. Journal of Essential Oil Research, v.7, n.5, p.541-543, 1995.

ZOTTI, M.; et al. Onychomycosis: First Case Due to Aspergillus nomius. Acta dermato-venereologica, v.91, n.5, p.591-592, 2011. 